\title{
Influence of Funding Sources and Business Diversification on the Financial Performance of Regional Water Company Jayapura Regency
}

\author{
Mugiati \\ University of Science and Technology Jayapura, Indonesia \\ a.mugiati@yahoo.com
}

\begin{abstract}
To examine and analyze the influence sources of funding consisting of long-term debt and capital to diversification business and financial performance of Regional Water Company Jayapura Regency. Methods of collecting data used were observation, interviews and secondary data such as financial statements and other documents that have to do with research. Data were analyzed descriptively and quantitatively using the financial ratio analysis, Du Pont analysis and financial ratios specified by Decree 47 of 1999 . The results showed that: the effect on the long-term debt diversification Regional Water Company Jayapura regency primarily on the acquisition of Long-Term Debt laba. Dan also affect the financial performance of Regional Water Company redgional Water Company Jayapura regency precisely at the level of solvabilitas, where based on research results Regional Water Company Jayapura Regency has a high level of solvabilitas, high solvabilitas is caused by injection of funds from the government charged as long-term debt. The use of equity capital effect on business diversification and financial performance of the Regional Water Company Jayapura regency. This is evidenced by a decrease in profit resulting from lower equity and the amount of long-term debt. Which due to the lack of balance between long-term debt and equity. And diversification efforts affect the financial performance of the Regional Water Company Jayapura Regency
\end{abstract}

\section{Keyword: Resources of Funding, Diversification, Financial Performance}

\section{Introduction}

The Regional Water Company Jayapura Regency as Regional Owned Enterprises (enterprises) are specially engaged in water management is expected to contribution optimally meet the water needs of society and contribution to local revenues. Regional Water Company Jayapura Regency in order to provide water service to the public is confronted by various obstacles, especially the financial crisis and economic downturn since mid-1997, which shook the joints of many people's lives, as well as business continuity in the field of water management. Constraints in question, either in relation to financial constraints and the rising price of materials the company's operational needs, so that if this continues could of course lead to costs incurred far greater than the revenue generated. Regional Water Compani Jayapura Regency that serves as the manager of clean water and at the same time a source of local revenues, are required to have a healthy financial performance for its survival in the future. Regional Water Company Jayapura Regency as manager of the expected role of clean water to meet the needs of cleans water to the community and can contribute to local revenues. With it required to always have a healthy financial performance, to its survival in the future. In doing water service to the community confronted over various obstacles related to both financial constraints and rising prices for materials company's operational needs, so that the costs incurred far greater than the revenue generated, consequently Regional water compani Jayapura Regency suffered losses every year for 5 (five) last year. The losses, caused by low levels of financial performance Regional Water Compani Jayapura Regency. So with the necessary research to find out more on the company in question, by analyzing data on the financial statements of the company, which is derived from the balance sheet and profit and loss.

\section{Literature Review}

Van Horne \& Wachowics (2002: 2) argues that financial management is as activities related to the acquisition financing and asset management with some of the overarching goal. Riyanto (2001: 13) says that, in essence financial management problems are related to the financial balance of the company. Thus the financial management holds the balance between assets and liabilities is required, along with the search for the qualitative composition of the assets and liabilities as well as possible. Selection of the qualitative 
composition of the assets will determine the structure of the company's assets; sedangakn election qualitative composition of liabilities will determine the company's capital structure. To be able to get a picture of a company's financial development in the necessary financial data reflected in the financial statements. Munawir (1993: 13) says balance is a systematic statement of assets, liabilities and capital of a company at a time tertentu. Tujuan balance sheet is to show the financial position of a company at a certain date, usually at the time when the books are closed and determined the end of the period remaining on a physical or calendar year. Weston and Thomas (1993: 17) explain that, both the balance sheet and income statement contains the presentation of the company in the past and may provide clues to the establishment of policies in the future. According to Riyanto (2001: 325) reveals that, connecting elements of various assets to each other and the elements of the various liabilities to each other and connecting the elements of assets and liabilities at a given moment can be obtained much description of the position or financial condition of a company. Sartono (1994: 45) argues that, financial ratio analysis is the main tool of a wide range of financial analysis, because the analysis is able to answer questions about the company's financial condition. So the financial ratio is an effort to standardize financial information so as to produce a useful comparison. Van Horne \& Wachowics (2002: 133) argues that, financial ratios or indices that connects two accounting numbers and is obtained by dividing one number by another number.

\section{Methodology}

Decree of the Minister of Interior of the Republic of Indonesia Number 47 of 1999 dated May 13, 1999. Thus the results of the analysis of financial ratios, can give an idea of the level of financial performance of the Regional Water District Jayapura.

1) The ratio of long-term debt to equity: This ratio is meant to assess the balance between the two sources of funding used to finance corporate assets, capital and debt. The use of loan funds that exceed the balance of the equity would have an impact on high interest expense to be borne and will result in low ability to generate profits, while the value of the performance indicators as follows:

\begin{tabular}{|c|c|}
\hline \multicolumn{2}{|l|}{ Ratio } \\
\hline$<=0,5$ & 5 \\
\hline$>0,5 \mathrm{~s} / \mathrm{d} 0,7$ & 4 \\
\hline$>0,7 \mathrm{~s} / \mathrm{d} 0,8$ & 3 \\
\hline$>0,8 \mathrm{~s} / \mathrm{d} 1,0$ & 2 \\
\hline$>1,0$ & 1 \\
\hline \multicolumn{2}{|c|}{$\begin{array}{l}\text { Formula of long-term debt ratio to equity } \\
\text { Long-term debt }\end{array}$} \\
\hline
\end{tabular}

2) The ratio of operating profit before depreciation cost of the principal and interest due: This ratio is used to measure the potential of the profit generated to fulfill the obligation to pay the principal and interest due. The aim is to measure the extent of industrial development financed with loan funding source can generate income to meet the obligations associated with the loan income, the value of the performance indicators as follows:

\begin{tabular}{|c|c|}
\hline Ratio & Value \\
\hline$>2,0$ & 5 \\
\hline$>\quad 1,7 \mathrm{~s} / \mathrm{d} 2,0$ & 4 \\
\hline$>\quad 1,3 \mathrm{~s} / \mathrm{d} 1,7$ & 3 \\
\hline$>\quad 1,0 \mathrm{~s} / \mathrm{d} 1,3$ & 2 \\
\hline$<=1,0$ & 1 \\
\hline
\end{tabular}

Formula operating profit ratio before depreciation costs against the principal and interest maturity: 


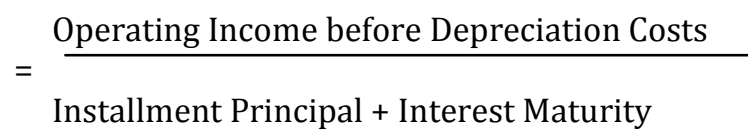

Of the two indicators then, the value of financial performance taps can be formulated as follows:

Financial performance value $=\frac{\text { The total value of the indicator }}{\text { The maximum value of indicator }} x$ weight
$\begin{aligned} & \text { Where: } \\ & \text { The maximum value of the indicator } \quad=60,- \\ & \text { Weight }\end{aligned}$

Based on the decision of the Minister of Interior No. 47 of 1999 dated May 31, 1999 such that the level of financial performance taps divided by five (5) categories:

\section{Category \\ Financial Performance}

$\begin{array}{ll}\text { a. } & \text { Excellent } \\ \text { b. } & \text { Good } \\ \text { c. } & \text { Enogh } \\ \text { d. } & \text { Less } \\ \text { e. } & \text { Not Good }\end{array}$

\section{Value} Financial Performance

$>75$

$>60-75$

$>45-60$

$>30-45$

$<=30$

\section{Results}

Assessment of financial performance Regional Water Company Jayapura Regency systematically done using taps financial performance appraisal system set out in the decision interior minister of the Republic of Indonesia Number: 47 of 1999. The assessment results once used to test the research hypothesis that Regional Water Company Jayapura Regency are healthy or unhealthy, Referring to the guidelines for assessment of financial performance taps, by decision of the interior minister of the Republic of Indonesia Number: 47 of 1999, the financial performance of Jayapura District 2008-2012 can be done by first calculating the value of the company's financial performance indicators, which are presented in Table 1 as follows:

Table 1: Calculation of Financial Performance Ratio Regional Water Company Jayapura Regency Year 2008-2012

\begin{tabular}{|c|c|c|c|c|c|c|c|}
\hline No & $\begin{array}{l}\text { Financial } \\
\text { Performance } \\
\text { Indicators }\end{array}$ & Ratios Formulas & $\begin{array}{l}\text { Ratio } \\
2008\end{array}$ & $\begin{array}{l}\text { Ratio } \\
2009\end{array}$ & $\begin{array}{l}\text { Ratio } \\
2010\end{array}$ & $\begin{array}{l}\text { Ratio } \\
2011\end{array}$ & $\begin{array}{l}\text { Ratio } \\
2012\end{array}$ \\
\hline 1 & 2 & 3 & 4 & 5 & 6 & 7 & 8 \\
\hline 1 & $\begin{array}{l}\text { The ratio of long-term } \\
\text { debt to equity }\end{array}$ & $\frac{\text { Long-term }}{\text { Equities }}$ & 0,38 & 0,44 & 0,28 & 0,24 & 0,23 \\
\hline 2 & $\begin{array}{l}\text { Ratio operating profit } \\
\text { before depreciation } \\
\text { charges against the } \\
\text { principal and interest } \\
\text { maturity }\end{array}$ & $\begin{array}{l}\text { Operating Income } \\
\text { before Depreciation } \\
\text { Principal + Interest due }\end{array}$ & 3,56 & 2,81 & 0,78 & $(1,98)$ & 0,97 \\
\hline
\end{tabular}

Source: Processed Data 
The table above calculation shows that, Regional Water Company Jayapura Regency in 2008 to obtain the total value of financial performance indicators by 10, thus still below that stipulated in the Decree of the Minister of Interior of the Republic of Indonesia No. 47 of 1999 which is the maximum value of 10 for two indikator . Later in 2009 gained a total of 10 , whereas in 2010 gained a total of 6 (reduced by 4 of the maximum value), then in 2011 declined again by 6 (decreased by 4 from the maximum value), and in 2012 decreased by a total of 6 ( 4 is reduced from the maximum value). Based on the table 3 above Regional Water Company Jayapura Regency in 2008 to obtain the value of financial business is 100, this means the value obtained on the classification of the value of financial performance greater than 45 in the Decree of the Minister of Interior of the Republic of Indonesia Number: 47 of 1999, so that the level of financial performance achieved quite enough (quite healthy). Then in 2009 obtained a value of 100 performance (Excellent), where in 2010 value by 60 (Good), 2011 velue in 60 (good), and year 2012 value by 60 (Good). Long-term debt affects the financial performance of Regional water company Jayapura Regency is to cost interest bicause the regional water company Jayapura Regency to get aid resource of fanding from local goverment, and makes cost interest so regional water company Jayapura Regency losses from year to year.

Table 2: Value Calculation of Financial Performance Indicators Regional Water Company Jayapura Regency Year 2008-2012

\begin{tabular}{|c|c|c|c|c|c|c|c|}
\hline No & $\begin{array}{l}\text { Financial } \\
\text { Performance } \\
\text { Indicators }\end{array}$ & Ratios Formulas & $\begin{array}{l}\text { Ratio } \\
2008\end{array}$ & $\begin{array}{l}\text { Ratio } \\
2009\end{array}$ & $\begin{array}{l}\text { Ratio } \\
2010\end{array}$ & $\begin{array}{l}\text { Ratio } \\
2011\end{array}$ & $\begin{array}{l}\text { Ratio } \\
2012\end{array}$ \\
\hline 1 & 2 & 3 & 4 & 5 & 6 & 7 & 8 \\
\hline 1 & $\begin{array}{l}\text { The ratio of long-term } \\
\text { debt to equity }\end{array}$ & $\begin{array}{l}\text { Long-term } \\
\text { Equities }\end{array}$ & 5 & 5 & 5 & 5 & 5 \\
\hline 2 & $\begin{array}{l}\text { Ratio operating profit } \\
\text { before depreciation } \\
\text { charges against the } \\
\text { principal and interest } \\
\text { maturity }\end{array}$ & $\begin{array}{l}\text { Operating Income } \\
\text { before } \quad \text { Depreciation } \\
\text { Principal }+ \text { Interest due }\end{array}$ & 5 & 5 & 1 & 1 & 1 \\
\hline & JUMLAH & & 10 & 10 & 6 & 6 & 6 \\
\hline
\end{tabular}

Source: Processed Data

Table 3: Calculation of Financial Performance Assessment Regional Water Company Jayapura Regency Year 2008-2012

\begin{tabular}{|c|c|c|c|c|c|c|c|}
\hline Year & Discription & & $\begin{array}{l}\text { Total value } \\
\text { Indicator }\end{array}$ & Weight & $\begin{array}{l}\text { Maximum } \\
\text { value of } \\
\text { Indicator }\end{array}$ & $\begin{array}{l}\text { Value of } \\
\text { Financial } \\
\text { Performance } \\
(6=\underline{3 \times 4}) \\
\quad 5\end{array}$ & $\begin{array}{l}\text { The Level of } \\
\text { Financial } \\
\text { Performance }\end{array}$ \\
\hline 1 & 2 & & 3 & 4 & 5 & 6 & 7 \\
\hline 2008 & $\begin{array}{l}2 \text { financial } \\
\text { indicators }\end{array}$ & performance & 10 & 100 & 10 & 100 & Excellent \\
\hline 2009 & $\begin{array}{l}2 \text { financial } \\
\text { indicators }\end{array}$ & performance & 10 & 100 & 10 & 100 & Excellent \\
\hline 2010 & $\begin{array}{l}2 \text { financial } \\
\text { indicators }\end{array}$ & performance & 6 & 100 & 10 & 60 & good \\
\hline 2011 & $\begin{array}{l}2 \text { financial } \\
\text { indicators }\end{array}$ & performance & 6 & 100 & 10 & 60 & good \\
\hline 2012 & $\begin{array}{l}2 \text { financial } \\
\text { indicators }\end{array}$ & performance & 6 & 100 & 10 & 60 & good \\
\hline
\end{tabular}


Regional Water Company Jayapura Regency has a low rate of return and it is also its return on investment is very low, and this is because the company obtained profit margin is relatively smaller than the zero (gain value minus). And the total cost is much greater than the income earned, as well as lower the total asset turnover, which is due to due to investments in the total assets are less productive..Guided by the decision of the Minister of Interior No. 47 of 1999, Regional Water Company Jayapura Regency has a financial level decreased from $2008 \mathrm{~s} / \mathrm{d}$ of 2012. The level of financial performance terkhir that in 2012 obtained PDAM Jayapura Regency is categorized as less healthy. Factors that have a strong influence on lowering the level of financial performance Regional Water Company Jayapura Regency is not yet optimal utilization of assets, and the imbalance in the structure of financing of assets that are significantly housed in debt resulting in higher interest expense, and waste in finance operational activities.

\section{Conclusion and Recommendations}

- To the leadership of regional water company Jayapura regency, in order to conduct negotiations on the part of creditors to reschedule the payment of loans and interest long-term loans of up to five years into the future, so using it easy to fix the financial performance.

- In an effort to increase the liquidity and solvency of the company, are expected to no longer carry out a new loan, but made additional equity capital through the allocation of revenue and expenditure budget (APBD) district budget every year.

- It is expected that Regional Water Company Jayapura regency, can enhance the accounts receivable turnover rate, by increasing the number of violations to increase the sales volume of water, monitoring and control of pipeline leaks and intensify collection of accounts receivable every year especially.

- And most importantly, it is expected to Regional Water Company Jayapura regency, to seek to increase return on investment by improving profit margins and asset turnover of the company, namely by pressing the operating costs and increase revenue both to increase sales volume and an increase in selling price / installation water connections on the customer gradually

\section{References}

Munawir, S. (1993). Financial Statement Analysis, Fourth Edition, Publisher Liberty, Jakarta.

Riyanto, B. (2001). Spending Basics Company, Fourth Edition. Publisher Liberty,

Sartono, A. (1994). Financial Management (Theory and Application), First Edition, First Printing, Publishing BPFE, Gadjah Mada University, Yogyakarta.

Van Horne, J. C. \& Wachowics, J. R. J. M. (2002). Principles of Financial Management, Ninth Edition, Publisher Salemba Four, Jakarta.

Weston, J. F. \& Copeland, T. E, (1993). Managerial Finance, 9Th Edition, Dryden Press, New York. 